1

О.Э. Гуревич - Б. Кербле

Отправлено

28. XI. 1966 г.

Благодарю Вас сердечно за то, что Вы извлекли из небытия труды и имя Александра Васильевича Чаянова. Вы проявили к моему покойному мужу столько душевного тепла, как будто Вы лично знали его близко и хорошо. Ваша прекрасная статья ${ }^{3}$ глубоко взволновала меня. Несмотря на все это, я вынуждена Вас просить не печатать брошюру «Путешествие моего брата Алексея в страну крестьянской утопии». Вы видите в ней причуду автора, но хорошо понимаете, что эта (причуда» стала для него фатальной в 1930 г. Эта брошюра и сейчас еще может быть воспринята, как политический выпад. Ради его памяти, которую мне бы не хотелось излишне омрачать, я и обращаюсь к Вам с этой просьбой.

Раз уж я заговорила об этой брошюре, хочу сказать Вам, что Александр Васильевич в своих артистических вкусах далеко не всегда солидаризировался со своим героем Кремневым. Он не любил, как и большинство интеллигенции его поколения, (передвижников». Ему были близки художники, принадлежавшие к группе «Мир искусства». Он очень любил русскую, да и не только русскую старину. У нас были: любовно им собранная небольшая коллекция русских икон XIV-XV вв., хорошее собрание гравюр (деревянная и на меди) XV-XVI вв., в основном итальянцы и немцы; любил старинный фарфор (русский), старинное стекло. Как видите, вкус у него был гораздо более тонкий, чем у Кремнева.

Что касается его близости к теософам, то в этом Вы просто ошибаетесь. Он совсем был не знаком с этого рода “философией») (если можно ее так назвать), и как-то в Берлине знакомый, увлекавшийся теософией, дал ему почитать книжку, в которой излагалось их учение. Александр Васильевич просмотрел ее, посмеялся и полный недоумения сказал: “Как можно тратить столько душевных сил на такие мелкие дела?»

3. По просьбе наших ученых я сейчас перевожу ее на русский язык. - Прим. О.Э. Гуревич. 
Сообщаю Вам дату рождения и смерти Александра Васильевича $17(29) .01 .1888$ г. - 20.03.1939 г. ${ }^{4}$ и основные жизненные вехи.

ТЕОРИЯ

Отец Александра Васильевича работал на Иваново-Вознесенской ткацкой фабрике. Начал с мальчика, растирающего краски, а потом стал пайщиком этой фабрики.

Мать - родом из купеческой семьи. Родилась в г. Вятке, окончила Московский сельскохозяйственный институт в первой группе женщин, допущенных в этот институт ${ }^{5}$. Так что Чаянов - интеллигент только во втором поколении.

Учился в Московском сельскохозяйственном институте (впоследствии Петровская сельскохозяйственная академия, а потом - Тимирязевская сельскохозяйственная академия), который и окончил в $19 \circ 9$ г. ${ }^{6}$ В этом же году его командируют в Бельгию (Льеж) для изучения организации всех форм кооперации.

Ещё в бытность свою студентом последних курсов он начал исследовательскую работу по льну, теории потребительно-трудового хозяйства и по кооперации в сельском хозяйстве.

В 1910 г. оставлен в Московском сельскохозяйственном институте на кафедре сельскохозяйственной экономии и организации сельского хозяйства. В этом же году он избран преподавателем Народного университета им. А.Л. Шанявского по курсу «География и история хозяйственного быта». В 1910 г. Чаянов избран действительным членом “Общества взаимопомощи русских агрономов».

В 1911 г. Чаянов командируется Департаментом земледелия в Швейцарию (Берн) (...для подготовки к занятию кафедры сельскохозяйственной экономии)?

В 1913 г. по возвращении из-за границы назначается преподавателем Московского сельскохозяйственного института. В 1919 г. $^{8}$ получает звание профессора Петровской сельскохозяйственной академии.

В 1919 г. проф[ессор] А.В. Чаянов назначается заведующим (Высшим семинарием сельскохозяйственной экономии и политики» при Петровской сельскохозяйственной академии.

4. Действительная дата смерти А.В. Чаянова была рассекречена в 1987 г.: он был расстрелян 3 октября 1937 г.

5. Факт окончания МСХИ матерью А.В. Чаянова - Е.К. Чаяновой - документально не подтвержден. В анкете 1921 г. А.В. Чаянов писал в графе «профессия родителей», что мать - учительница (РГАЭ. Ф. 731. Оп. 1. Д. 9о. Л. 22).

6. А.В. Чаянов окончил курс обучения в 1910 г., диплом ученого агронома І разряда получил в 1911 г.

7. А.В. Чаянов был командирован Главным управлением земледелия и землеустройства (ГУЗиЗ) за границу на один год. Программа занятий предполагала посещение Германии, Швейцарии, Франции, Англии (РГАЭ. Ф. 731. Оп. 1. Д. 41, 42).

8. По декрету Совнаркома от 1 октября 1918 г. всем ведущим преподавателям вузов РСФСР присваивалось единое ученое звание профессора. 
В 1922 г. по предложению Наркомзема РСФСР был организован А.В. Чаяновым «Всесоюзный научно-исследовательский институт сельскохозяйственной экономии и политики», затем переименованный сначала в НИИ крупного социалистического хозяйства, а затем в Колхозный институт 9 . В 1924 г. из академии этот институт переехал в Москву в Хоромный тупик. Впоследствии многие аспиранты, окончившие этот институт, заняли руководящие посты в сельскохозяйственных институтах нашего Союза. В 1927 г. Чаянов организовал издание “Бюллетеня сельскохозяйственной экономии». Затем бюллетень переменил свое название и стал выходить, как “Труды научно-исследовательского института сельскохозяйственной экономии» ${ }^{10}$.

О его практической работе в области сельского хозяйства, не считая сельскохозяйственной кооперации, могу сказать, что Чаянов принимал активное участие в разработке проекта самого крупного хлопководческого совхоза (Пахта Арал», не потерявшего своего значения до сегодняшнего дня. Принимал активное участие в организации (Зернотреста).

Кроме того, может быть, это вам покажется нужным для его характеристики, он страстно был влюблен в Москву и занимался исследованием ее глубокого прошлого. Он восстановил карту Москвы XVII в. ${ }^{11}$ и в Московском государственном университете читал курс по истории топографии г. Москвы. О его литературных пробах Вам известно, поэтому ничего не пишу. Если Вас интересует карта, могу ее передать д[окто]ру проф[ессору] А.Л. Вайнштейну.

\section{Уважающая Вас и благодарная Ольга Гуревич (Чаянова) РГАЭ. Ф. 731. Оп. 2. Д. 19. Л. 1-4. Машинопись.}

9. В 1929 г. НИИСХЭ был слит с Институтом крупного хозяйства, образован Институт организации крупного хозяйства и сельскохозяйственной экономики, в 1930 г. последний был реорганизован в Колхозный институт. Подробнее см.: Овиинцева Л.А. К истории научно-исследовательского института сельскохозяйственной экономии // Аграрная экономика и политика: история и современность / Отв. ред. А.В. Петриков. М., 1996. С. 50-54.

10. “Бюллетень государственного научно-исследовательского института сельскохозяйственной экономии» и “Труды» НИИСХЭ - разные издания. (Труды» выходили с 1921 года.

11. План г. Москвы XVII века. Составлен проф. А. Чаяновым в 1920 году. План составлен на основании “Строельной книги Московским церквам 1657 года», переписных и других книг 1620, 1626 и 1638 годов, планов Ив. Мичурина 1739 г. и Хотева 1854 года. Улицы проведены для Китая и Белого Города сообразно планам XVII века из атласов Merian’a и Blavian'a, а для Земляного и Замоскворечья сообразно плану Meerber'a. Частные поправки внесены по мелким планам, опубликованным гг. Ламанским и Белокуровым. РСФСР. - Главмузей. Науино-методический отдел (РГАЭ. Ф. 731. Оп. 1. Д. 2о).

О.Э. Гуревич, Б. Кербле ...переписка О.Э. Гуревич и Б. Кербле 
2

Б. Кербле - О.Э. Гуревич

теория Париж, 7 июня 1967 года.

Уважаемая госпожа Гуревич!

Мой коллега Д. Торнер передал мне Ваше любезное письмо от 28-го мая. Я прежде всего хотел бы поблагодарить Вас за Ваше учтивое внимание. Я в самом скором времени получу Вашу посылку и, смею Вас заверить, я в полной мере понимаю ее художественную ценность, так как мне хорошо известны работы палехских мастеров. Очень жаль, что проекты профессора Вайнштейна были перенесены на более поздний срок.

Я хотел бы успокоить Вас относительно произведения, которое Вы не получили. Я не послал его, так как не знал, насколько это будет уместно, исходя из Вашего предыдущего письма. Сегодня я отправляю его Вам заказной бандеролью на ул. Дмитриевского. Я дарю его Вам с преогромным удовольствием.

Остается заданный Вами вопрос об издании крестьянской утопии. Инициатива этого переиздания принадлежит не мне, по этой причине у меня нет возможности повлиять на этот проект. Но я могу заверить Вас, что передал Ваше письмо и отстаивал Вашу точку зрения: безрезультатно. В любом случае это издание выйдет на русском (этот текст уже хорошо известен специалистам и вполне доступен в западных библиотеках); поэтому не стоит опасаться скандальной рекламы и еще менее - политических спекуляций. Вы знаете тон моей работы о Вашем муже и предосторожности, предпринятые мною с целью избежать спорных отзывов. Я слишком уважаю русский народ - как его прошлое, так и его труд в настоящем - чтобы вступить на этот путь.

Я прошу Вас, уважаемая госпожа, принять выражение моего уважения и глубокого почтения.

Б. Кербле

РГАЭ. Ф. 731. On. 1. Д. 10\%. Л. 1. Авторизованная мащинопись.

3

Б. Кербле - О.Э. Гуревич

Париж, 10 ноября 1967

Уважаемая госпожа!

Прошу простить меня за то, что с некоторой задержкой отправляю Вам этот фрагмент, который я позволил себе опубликовать, полагая, что он позволит лучше понять личность Александра Васильевича. Я использую эту возможность, чтобы сказать Вам, насколько тронуло меня Ваше письмо, и еще раз отблагодарить за изящный маленький шедевр из Палеха, который я получил. 
Я прошу Вас, уважаемая госпожа, принять выражение моего уважения и глубокого почтения.

$$
\begin{array}{r}
\text { Базиль Кербле } \\
\text { РГАЭ. Ф. 731. Оп. 1. Д. 1о\%. Л. } 10 . \\
\text { Автограф. }
\end{array}
$$

О.Э. Гуревич, Б. Кербле ...переписка О.Э. Гуревич и Б. Кербле

4

Б. Кербле - О.Э. Гуревич

56, Рю Вано, Париж, 7 округ

10 января 1969 года.

Уважаемая госпожа!

От всего сердца направляю в начале Нового года свои наилучшие поздравления Вам и всем, кто Вам дорог. Избранные произведения Александра Васильевича вышли в виде восьми прекрасных томов в небесно-голубой обложке в последние недели 1968 года. Это издание на русском языке, выпущенное в Англии (S.R. Publisher Ltd., East Ardsley, Wakefield, Yorks.), но под научным руководством Практической школы высших исследований в Сорбонне, к которой я принадлежу. Я попросил Школу отправить Вам эти восемь томов заказной бандеролью по указанному Вами новому адресу. Я думаю, Вы получите это собрание сочинений не позднее чем через два месяца (необходимо время для пересылки из Уэйкфилда в Париж, затем из Парижа в Москву, на Луну сегодня можно попасть быстрее!). Теперь же в научных журналах вышли весьма хвалебные отзывы на произведение, выпущенное по-английски в 1966 году ${ }^{12}$, особенно в Японии от Р.Ф.Э. Смита в $\underline{\mathrm{CHUSO}}$ (весна 1967), в Англии от экономиста из кембриджского Тринити Колледж Мориса Добба в The Economic Journal (июнь 1968), от экономиста Колина Кларка в Soviet Studies (Глазго, октябрь 1967), во Франции

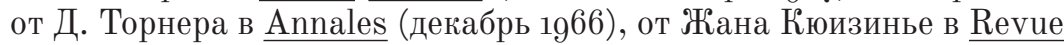
francaise de Sociologie, том VII, 1967 и т. д. ${ }^{13}$ Сам я часто в своих лекциях и статьях упоминаю произведения $A . B .$, всякий раз с чувством глубокой признательности за то, чему он меня научил.

$$
\begin{array}{r}
\text { С глубоким уважением, } \\
\text { Базиль Кербле } \\
\text { РГАЭ. Ф. э31. Oп. 1. Д. 10\%. Л. 110б-12. } \\
\text { Автограф. }
\end{array}
$$

12. Очевидно, речь идет о книге: Chayanov A.V. The theory of peasant economy / Ed. by D. Thorner, B. Kerblay, R.E.F. Smith. Homewood, Illinois, 1966. - XXV, 317 p.

13. Оценка моих работ В.Г. Сироткиным, которую нельзя назвать негативной, появилась в “Вопросах истории». 1968. №2. С. 199, где цитируется моя статья 1964 года. - Прим. Б. Кербле. 
5

Б. Кербле - О.Э. Гуревич

теория Париж, 31 декабря 1969 года.

Уважаемая госпожа!

Я только что получил великолепную книгу гравюр с видами старого Петрограда, родного города моей матери, который я впервые с восторгом открыл для себя в 1955 году. К счастью, мы в Париже имеем возможность без всякого труда следить за стремительным развитием Вашей страны, в основном благодаря книжным магазинам, специализирующимся на продаже советских книг. Это позволило мне закончить работу о городе Москве, которая вышла в прошлом году, в настоящее же время я заканчиваю другую работу, посвящённую всем новым городам (которая будет опубликована в “Анналах» - журнале Практической школы высших исследований). Излюбленной темой моих исследований остается жизнь крестьян - моя докторская диссертация посвящена крестьянским рынкам в СССР, а также избе; именно поэтому открытие трудов Александра Васильевича было столь важным моментом в моем развитии. Я рад, что сегодня они становятся известны все более и более широкой публике. Исследования, появившиеся последнее время в Англии (А. Ноув "An economic History of USSR") и во Франции (А. Мендра и Тавернье (Земля, крестьяне и политика»), ссылаются на А.В. Кстати, профессор Гельфат опубликовал в "Archives Internationales de Sociologi de la Coopération» статью, которую он должен был Вам отправить, так как он попросил у меня Ваш адрес. Я также этим летом написал посвященное ему небольшое сочинение (оно выйдет по-английски в многотиражном карманном издании (Пингвин)).

$\mathrm{C}$ моим глубочайшим уважением посылаю самые теплые пожелания Вам и всем Вашим.

Базиль Кербле С самыми лучшими преданными воспоминаниями Базиль Кербле

P.S. Спасибо за Вашу открытку. Кониина профессора Вайнштейна - огромная потеря для нас всех. Я присоединяюсь к вашим соболезнованиям. РГАЭ. Ф. 731. On. 1. Д. 10\%. Л. 4. Aвтографб.

6

О.Э. Гуревич - Б. Кербле

1.III.70. Basile Kerblay

Cher Monsieur,

Как странно, Ваша мать родилась в Петрограде, а я родилась в Париже и провела там все свое детство (отец мой был политэми- 
грантом). Вы пишете, что в первый раз были в Ленинграде в 1955 г. Стало быть, Вы там были. А в Москве? После вашего последнего письма я лучше понимаю, почему Александр Васильевич, как человек, Вам так понятен. Наверное, потому, что у вас такие же разносторонние интересы, как у него. Кроме Вашего и его любимого сельского хозяйства Вы пишете о Москве, о наших новых городах, Вы знаете и любите наших народных мастеров. Благодарю Вас за Ваши письма, хотя и редкие, они всегда мне доставляют большое удовольствие.

А теперь простите меня за то, что я хочу Вам написать. Я уверена, что с Вашей чуткостью Вы поймете меня правильно. Я получила от проф[ессора] Гельфата его статью ${ }^{14}$, в которой он пишет и об Александре Васильевиче. Я его не знаю и ничего плохого о нем не хочу сказать, но мне неприятно поддерживать какие-либо отношения со страной, с которой моя страна порвала дипломатические отношения ${ }^{15}$. Я восприняла это как большую бестактность с его стороны.

Еще раз простите меня за то, что я Вам написала, и прошу верить в мое искреннее к Вам уважение.

Olga Gourevitch

РГАЭ. Ф. 731. Оп. 1. Д. 10\%. Л. 14-140б. Рукописная копия.

7

Б. Кербле - О.Э. Гуревич

Париж, 20 ноября 1973

Уважаемая госпожа!

Я был очень тронут получением «Альманаха библиофила» (1973). Это прекрасная книга, посвящённая предмету, который роднит нас с теми, кто подобно Вам и Александру Васильевичу, о котором я также думаю, является любителем хороших книг. Эта работа также дорога всем тем, кто, подобно мне в Сорбонне, обязаны передавать следующим поколениям все лучшее из наследия прошлого.

Я по-прежнему продолжаю интересоваться настоящим, регулярно читая литературные (“Л[итературную]Г[азету]», «Новый

14. Guelfat I. A.V. Tchayanov propagateur de la pédagogie de la cooperation // Archives Internationales de Sociologi de la Coopération et du Développement. 1969. № 25. Оттиск статьи был прислан О.Э. Гуревич с дарственной надписью: «Госпоже Чаяновой на память и в память покойного А.В. Чаянова. Февраль 1970. Профессор Иерусалимского ун-та Исаак Гельфат» (РГАЭ. Ф. 731. Оп. 1. Д. 112).

15. Дипломатические отношения с Израилем были разорваны СССР в 1967 г., восстановлены в 1991 г. 
16 Мир», «Наш Современник»), а также научные журналы, чтобы участвовать в важных дебатах и понимать чаяния, которые вдохтеория новляют Ваш великий народ.

От всего сердца благодаря Вас за Ваше учтивое внимание, я заверяю Вас, моя уважаемая госпожа, в величайшем и преданном почтении.

\author{
Ваш Ле Кербле. \\ РГАЭ. Ф. 731. On. 1. Д. 10\%. Л. 13. \\ Aвтограф.
}

\title{
Basile Kerblay and Alexander Chayanov: At the crossroads of knowledge
}

Igor Kuznetsov, PhD (History), Senior Researcher, the School of Public Policy, Russian Presidential Academy of National Economy and Public Administration. 119571, Moscow, Vernadskogo Prosp., 82. E-mail: repytwjd68@mail.ru.

Tatiana Savinova, PhD (Economics), Head of Organizational-Methodical and Personnel Work Chair, Russian State Archive of Economics; 119992, Moscow, B. Pirogovskaya St., 17. E-mail: savinovazo@yandex.ru

The Russian Peasant Studies presents a collection of archival documents related to the publication of Alexander Chayanov's works in 1967 in France and England, which was prepared by the Professor of Sorbonne University Basile Kerblay. This collection includes the correspondence of Olga Gurevich, the widow of Chayanov, with Basile Kerblay in 1966-1970, and her translation from French of Kerblay's article on the work of Chayanov. Kerblay's article was published as a preface to the collected works of Chayanov and became classic. This is the first serious study of the biography and work of Chayanov and of the theory of the Russian organization-production school of the 1920 in Western sociology. This article is published in Russian for the first time. The letters of Kerblay and Olga Gurevich reveal some additional circumstances of the publication of Alexander Chayanov's works in 1967 and some features of the ideological atmosphere of the USSR at that time. The collection of archival documents in the Russian Peasant Studies includes comments and a brief biography of Olga Gurevich. These documents are a part of the funds of the Russian State Archive of Economics. This publication is dedicated to the anniversary of Chayanov.

Key words: theory of peasant economy, history of economic thought, organizationproduction school, Chayanov, Kerblay, Gurevich 